\title{
RNA-protein interaction methods to study viral IRES elements
}

\author{
Rosario Francisco-Velilla, Javier Fernandez-Chamorro, Gloria Lozano, Rosa Diaz-Toledano, \\ Encarnación Martínez-Salas*
}

Centro de Biología Molecular Severo Ochoa, Consejo Superior de Investigaciones Científicas - Universidad Autónoma de Madrid, Nicolas Cabrera 1, 28049 Madrid, Spain

\section{A R T I C L E I N F O}

\section{Article history:}

Received 15 April 2015

Received in revised form 25 June 2015

Accepted 30 June 2015

Available online 2 July 2015

\section{Keywords:}

RNA virus

IRES elements

RNA-binding proteins

RNA structure

Translation control

\begin{abstract}
A B S T R A C T
Translation control often takes place through the mRNA untranslated regions, involving direct interactions with RNA-binding proteins (RBPs). Internal ribosome entry site elements (IRESs) are cis-acting RNA regions that promote translation initiation using a cap-independent mechanism. A subset of positive-strand RNA viruses harbor IRESs as a strategy to ensure efficient viral protein synthesis. IRESs are organized in modular structural domains with a division of functions. However, viral IRESs vary in nucleotide sequence, secondary RNA structure, and transacting factor requirements. Therefore, in-depth studies are needed to understand how distinct types of viral IRESs perform their function. In this review we describe methods to isolate and identify RNA-binding proteins important for IRES activity, and to study the impact of RNA structure and RNA-protein interactions on IRES activity.
\end{abstract}

(c) 2015 Elsevier Inc. All rights reserved.

\section{Introduction}

Viral RNAs have evolved mechanisms to initiate translation different from cellular mRNAs. Most cellular mRNAs initiate protein synthesis using a mechanism that depends on the recognition of the $\mathrm{m}^{7} \mathrm{G}\left(5^{\prime}\right) \operatorname{ppp}\left(5^{\prime}\right) \mathrm{N}$ structure (termed cap) located at the $5^{\prime}$ end of mRNAs (reviewed in [1]). In contrast, the picornavirus genomic RNA initiate translation internally through a cis-acting region designated internal ribosome entry site (IRES) element, using a cap-independent mechanism [2,3]. Moreover, IRESs also drive translation initiation in hepatitis $\mathrm{C}$ virus (HCV), pestiviruses, dicistroviruses, retroviruses, and some plant RNA viruses [4-6].

IRESs differ in primary sequence, RNA structure and trans-acting factors requirement, hence promoting internal initiation throughout distinct mechanisms. The intergenic region (IGR) of dicistroviruses can assemble a preinitiation $48 \mathrm{~S}$ complex in the absence of any initiation factor [7]. The IGR consists of a three-pseudoknoted (PKI-III) RNA structure [8] in which PKI mimics a tRNA/mRNA interaction in the decoding center of the $40 \mathrm{~S}$ ribosomal subunit [9]. The HCV-like IRESs, also present in pestiviruses and some picornaviruses [10,11], represent the next level of complexity. These IRESs require eIF3 and the ternary complex (eIF2-GTP-metRNA $A_{i}$ ) to assemble $48 \mathrm{~S}$ initiation complexes in reconstitution assays [12]. The RNA structure of the HCV IRES is organized in conformationally flexible domains, designated II, III,

\footnotetext{
* Corresponding author.

E-mail address: emartinez@cbm.csic.es (E. Martínez-Salas).
}

and IV. Each domain performs a different function during internal initiation of translation. Domain III binds the 40S ribosomal subunit and eIF3; domain IV harbors the AUG initiation codon; and domain II is involved in eIF2-catalyzed GTP hydrolysis and 60S subunit joining. In addition, domain II contacts the ribosomal proteins RPS5 and RPS25, stabilizing the ribosome in a single conformation leading to translation initiation $[13,14]$. Concerning the interaction of viral IRESs with ribosomal proteins, recent evidences have shown that depletion of RPS25 in mammalian cells affects HCV and IGR IRES activity, and to a lower extent, picornavirus IRES function [15].

The highest level of complexity is so far found in picornavirus IRESs. These elements are diverse in primary sequence and secondary RNA structure, being classified into five different types [16]. Functionally related picornavirus IRESs harbor a common RNA structure core and sequence motifs maintained by evolutionary conserved covariant substitutions [17]. Assembly of $48 \mathrm{~S}$ initiation complexes into IRESs of entero-, cardio-, and aphthovirus requires eIF4G, eIF4A, eIF1, eIF3 and the ternary complex. In addition, host proteins designated IRES-transacting factors (ITAFs) contribute to IRES activity $[18,19]$. ITAFs are RNA-binding proteins (RBPs) also involved in splicing, RNA transport, or RNA stability [20], which generally do not contribute to the canonical cap-dependent translation initiation mechanism. Cleavage of host factors in picornavirus-infected cells by viral proteases (L, 2A and 3C) disrupts cap-dependent protein synthesis, in addition to affect transcription, nucleo-cytoplasmic transport, and RNA granules composition. This adverse situation for cellular gene expression, however, does not 
compromise IRES-dependent translation. Instead, all picornavirus RNAs evade translation inhibition and hijack the translation machinery taking advantage of host factor proteolysis products that, in some cases, activate IRES function [21].

Generally, IRES activity is determined as the expression of reporter genes from dicistronic or monocistronic reporter RNAs. In the first case, the expression of the second reporter gene is normalized to the protein expressed from the first cistron, which monitors cap-dependent translation. In the second case, protein synthesis driven by the IRESs should be normalized to the expression from another RNA, transfected in parallel. Additionally, when the expression is monitored from transfected plasmids, the constructs should be carefully analyzed for the absence of cryptic promoters and potential splicing events $[22,23]$. To measure IRES activity under conditions of cap-dependent inhibition, cells are transfected with the IRES reporter plasmids and a plasmid expressing the $\mathrm{L}$ protease of aphthovirus or the $2 \mathrm{~A}$ protease of enterovirus $[24,25]$. Both $2 \mathrm{~A}$ and $\mathrm{L}$ proteases induce the cleavage of eIF4G, among other host factors, inhibiting cap-dependent translation but allowing viral IRES-dependent translation. Alternative approaches to analyze IRES activity rely on viral cDNA clones within which parts of the genome can be modified. This approach allows determining protein synthesis within the viral RNA context [26], in addition to analyze potential effects of viral proteins and untranslated regions on IRES activity [27].

\section{RNA-affinity methods to study IRES-protein interactions}

IRES function depends on the interaction with host factors $[17,20]$. In turn, these factors interact within the cell with other proteins, which can influence IRES activity by indirect interactions. RNA-affinity methods to isolate and identify RBPs are crucial in RNA biology research. Identifying the interaction of proteins with RNA, as well as with other proteins, has been critical for the understanding of networks controlling gene expression. A variety of assays have been developed to capture RBPs bound to specific mRNA targets, and to determine the impact of RBPs on IRES-mediated translation using living cells, cell-free extracts or Xenopus oocytes [28-30]. RNA affinity chromatography followed by mass spectrometry (MS) analysis allows for a sensitive profiling of RNA-protein interactions. Combined with other molecular biology methodologies, this technique can determine RBPs recognizing specific RNAs and may also be used to study the significance of these targets in infected cells. Then, the influence of the candidate RBPs on the target RNA should be evaluated by silencing, or ectopically overexpressing the protein of interest. Further, the consequences of RBP manipulation can be studied by assessing target RNA stability and translation efficacy. Several approaches, described below, have been developed to identify proteins interacting with IRESs.

\subsection{Identification of IRES-binding proteins by RNA-affinity followed by mass spectrometry}

Proteomic approaches are often applied to identify RNA partners using affinity chromatography followed by mass spectrometry. For this, the RNA of interest is synthesized in vitro with convenient tags for which high affinity ligands are available. These can be either biotin label incorporated on the RNA or sequences added to the $5^{\prime}$ or $3^{\prime}$ end of the RNA, avoiding disrupting the functional RNA conformation. Illustrative examples are poly(A) tails, streptavidin aptamers, tobramycin (Tob)-aptamers, a short open reading frame and a streptomycin aptamer, hairpins recognized by high affinity ligand proteins (e.g. MS2), among other possibilities [31-34]. Additionally, RNA-protein interactions can be performed in the presence of a large molar excess of cytoplasmic
RNA (RNAc) or tRNA as a non-specific competitor, to eliminate the background of unspecific binding proteins. This methodology includes several steps, described below.

\subsubsection{RNA synthesis and cytoplasmic RNA preparation}

Plasmids expressing the RNA of interest with appropriate tags (Fig. 1A) should be prepared in advance. Then, in vitro transcription of the full-length or specific IRES domains is performed using T7 RNA polymerase (10-50 U) with linearized plasmid DNA (1$3 \mu \mathrm{g}), 40 \mathrm{mM}$ Tris- $\mathrm{HCl} \mathrm{pH}$ 7.9, $50 \mathrm{mM}$ DTT, $0.5 \mathrm{mM}$ rNTPs, during $1 \mathrm{~h}$ at $37^{\circ} \mathrm{C}$ [35]. Newly synthesized RNA is extracted with phenol-chloroform, ethanol precipitated and resuspended in TE (10 mM Tris- $\mathrm{HCl} \mathrm{pH} 8,1 \mathrm{mM}$ EDTA). RNA integrity is examined by denaturing gel electrophoresis.

Total RNAc is isolated from confluent mammalian cells grown in $10-\mathrm{cm}$ dishes, washed twice with cold phosphate buffer saline (PBS) and lysed in buffer C (50 mM Tris- $\mathrm{HCl} \mathrm{pH} 7.8,120 \mathrm{mM}$ $\mathrm{NaCl}, 0.5 \% \mathrm{NP} 40$ ) [36]. Following elimination of cellular debris, RNAc is extracted from cytosolic extract using TriPure isolation reagent (Boehringer Mannheim). RNAc is ethanol precipitated, resuspended in TE and then, the RNA concentration estimated from the OD measured at $260 \mathrm{~nm}$.

\subsubsection{Preparation of $\mathrm{S} 10$ cellular extracts}

For S10 cell extracts preparation BHK-21, HEK293 or HeLa cells are grown in $10-\mathrm{cm}$ dishes to $100 \%$ confluence. Then, cells are washed twice with cold PBS, scraped, and collected by centrifugation. The cellular pellet is resuspended in 1 volume of ice-cold hypotonic buffer (10 mM HEPES-KOH pH 7.4, $10 \mathrm{mM} \mathrm{KAc,}$ $1.5 \mathrm{mM} \mathrm{MgAc}, 2.5 \mathrm{mM}$ DTT) and homogenized by 30 strokes in a $1 \mathrm{ml}$ glass Dounce on ice. The cellular debris is eliminated by centrifugation at $5000 \times \mathrm{g}$ for $5 \mathrm{~min}$ at $4{ }^{\circ} \mathrm{C}$. The clear lysate is then spin down at $10,000 \times \mathrm{g}$ for $5 \mathrm{~min}$ at $4{ }^{\circ} \mathrm{C}$, adjusting the supernatant to $3 \%$ glycerol [36]. To prepare cap-independent cell extracts, eIF4G is proteolyzed by transfection of cells with a plasmid expressing the $\mathrm{L}$ protease of FMDV $12-16 \mathrm{~h}$ before extract preparation. Following elimination of cellular debris, the extract is further incubated at room temperature for 5-10 min to allow total cleavage of eIF4G by the L protease in the cell lysate. Monitoring of the presence of intact eIF4G in the S10 cell extracts as well as the extent of eIF4G cleavage in L-transfected cell extracts is performed by western blot assay [36]. Total protein concentration is measured by the Bradford assay (Biorad).

\subsubsection{Protein complexes identification by RNA affinity purification}

For constructs including a tract of adenines at the $3^{\prime}$ end of the RNA (Fig. 1A), transcripts $(2.5 \mu \mathrm{g})$ are incubated with oligo-dT magnetic beads (Life Technologies) (Fig. 1B) in binding buffer $(25 \mu \mathrm{l})(10 \mathrm{mM}$ Tris- $\mathrm{HCl} \mathrm{pH} 7.5,100 \mathrm{mM} \mathrm{KCl}, 2 \mathrm{mM} \mathrm{MgCl} 2)$ at $4{ }^{\circ} \mathrm{C}$ for $30 \mathrm{~min}$ on a rotating wheel [32]. Unbound RNA is removed, and the beads-RNA complexes are washed twice with binding buffer. Then, beads-RNA complexes are incubated with S10 extracts $(100 \mu \mathrm{g})$ prepared from BHK-21, HEK293 or HeLa cells (Fig. 1C) in the presence of a 100 -fold molar excess of RNAc or tRNA as non-specific competitors, at $4{ }^{\circ} \mathrm{C}$ during $15 \mathrm{~min}$. Unbound proteins are removed by washing with binding buffer, followed by two washes with $10 \mathrm{mM}$ Tris- $\mathrm{HCl} \mathrm{pH} 7.5,100 \mathrm{mM} \mathrm{KCl}, 0.5 \mathrm{mM}$ $\mathrm{MgCl}_{2}$. A small aliquot of the polypeptides associated to the RNA-beads are fractionated by SDS-PAGE in parallel to samples processed with a control RNA (Fig. 1D), and visualized by silver staining (Amersham). In parallel, the protein samples are processed for mass spectrometry analysis [29].

Alternative methods to identify RBPs make use of biotinylated RNAs [31] or streptavidin aptamer-tagged RNAs [33] (Fig. 1A), allowing RNA binding to streptavidin-coated magnetic beads (Fig. 1B). Subsequently, the beads-RNA complexes are incubated 
A

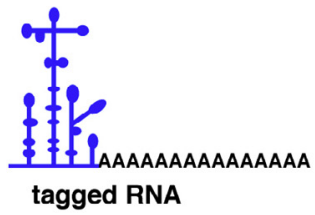

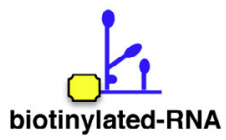

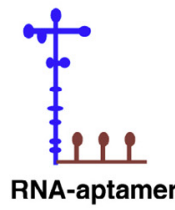

B
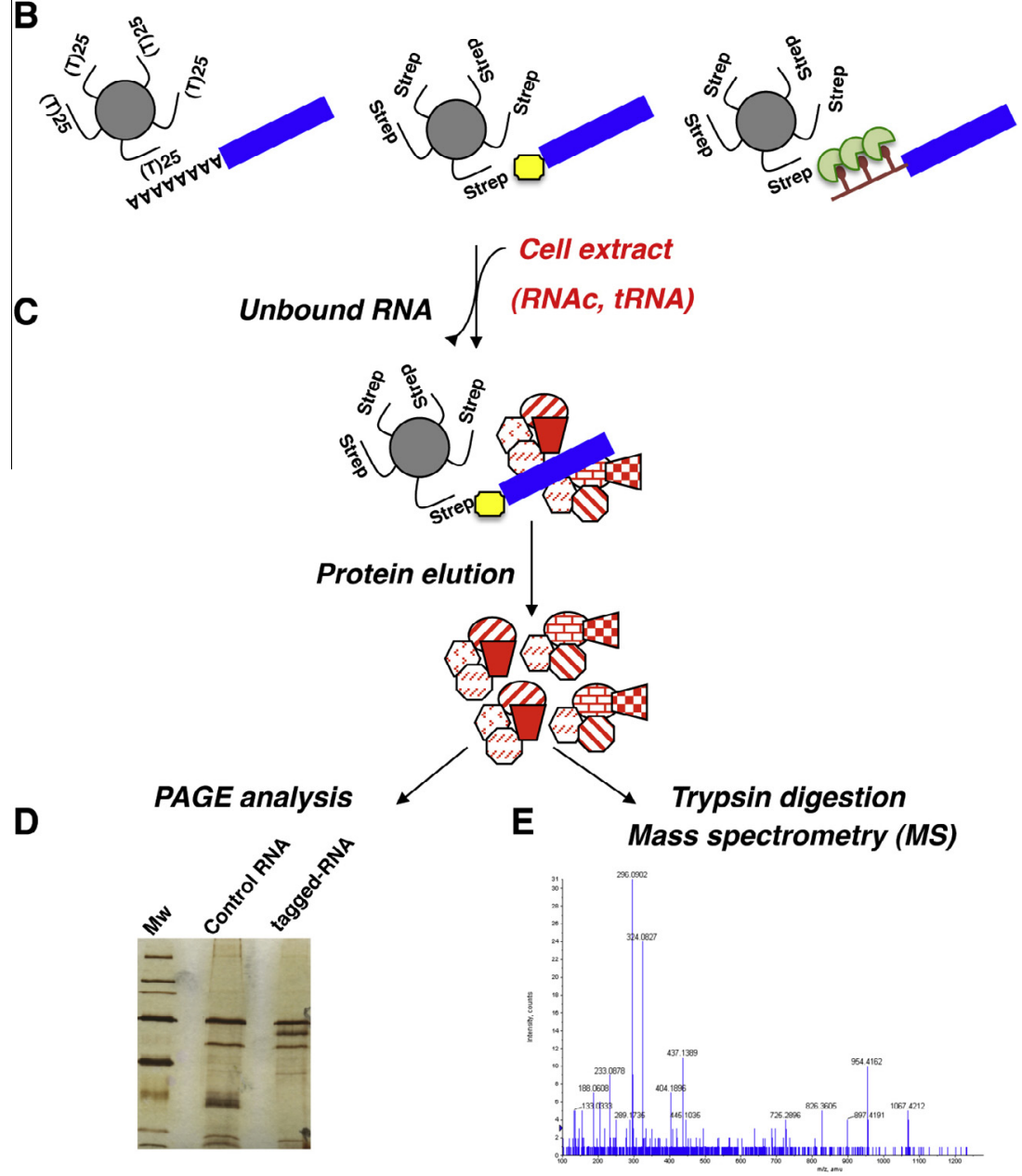

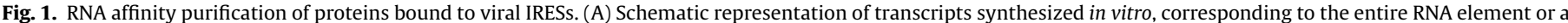

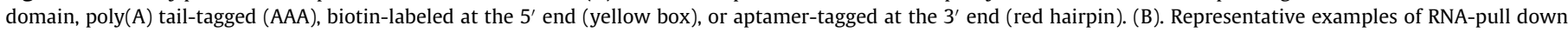

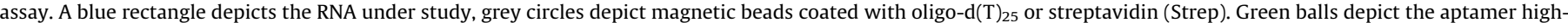

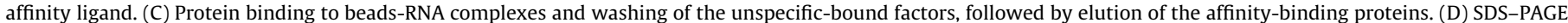

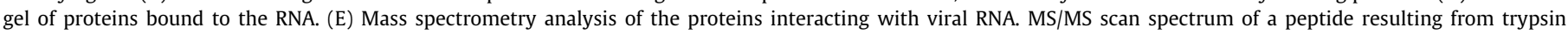
digestion.

with cellular extracts or the proteins under study (Fig 1C). Upon folding, the streptavidin aptamer sequence (5'-CGACCAGAAUCAU GCAAGUGCGUAAGAUAGUCGCGGGUCG-3) has high affinity for streptavidin. For biotinylated RNAs or constructs tagged with streptavidin aptamers, Dynabeads M-280 Streptavidin (Life Technologies) are used to capture RNA. Prior to incubate the beads with RNA, the beads suspension is treated with five volumes of washing buffer ( $5 \mathrm{mM}$ Tris- $\mathrm{HCl} \mathrm{pH} 7.5,0.5 \mathrm{mM}$ EDTA, $1 \mathrm{M} \mathrm{NaCl}$ ) 5 min with gentle rocking at room temperature, followed by 2 min on the magnet to discard the supernatant. Next, beads are cleaned of RNases and other contaminants by soaking once with solution A $(0.1 \mathrm{M} \mathrm{NaOH}, 0.05 \mathrm{M} \mathrm{NaCl})$ and twice with solution B $(0.1 \mathrm{M} \mathrm{NaCl})$. The clean beads pellet collected on the tube wall is resuspended in solution B $(100 \mu \mathrm{l})$. RNA binding is then carried out in a final volume of $500 \mu \mathrm{l}$ of binding buffer $(0.1 \mathrm{mM}$ HEPES-KOH pH 7.4, $6 \mathrm{mM} \mathrm{MgCl}_{2}, 0.1 \mathrm{M} \mathrm{NaCl}$ ) and RNA (20 pmol) during $30 \mathrm{~min}$ at room temperature rotating in a wheel. The beads-RNA complexes are collected in the tube wall standing on the magnet $3 \mathrm{~min}$, and the supernatant is removed, followed by three washes with binding buffer to eliminate unbound RNA (Fig. 1B).

\subsubsection{Mass spectrometry identification}

The RNA affinity-purification samples are appropriate to be analyzed by mass spectrometry (MS). Proteins bound to a control RNA are analyzed in parallel to identify unspecific binding proteins. For this, samples are applied onto a SDS-PAGE gel, stopping the run to concentrate the proteome in the stacking/resolving gel interface. Proteins are visualized by Coomassie blue staining, excised, cut into small cubes, distained, and digested with sequencing grade trypsin (Promega) [37]. The protein digest is analyzed by reverse phase-liquid chromatography (RP-LC)-MS/MS in 
an Easy-nLC II system coupled to an ion trap LTQ-Orbitrap-Velos-Pro mass spectrometer (Thermo Scientific). The peptides are concentrated and then eluted using a 90-min gradient from 5 to $40 \%$ of $0.1 \%$ formic acid, $80 \%$ acetonitrile in water. Electrospray ionization (ESI) is done using a Nano-bore emitters Stainless Steel ID $30 \mu \mathrm{m}$ (Proxeon) interface. The Orbitrap resolution is set at 30.000 . The mass spectrometer is operated in the selected MS/MS ion-monitoring mode (SMIM mode). The LTQ-Orbitrap-Velos-Pro detector is programmed to perform a continuous sequential operation in the MS/MS mode on the doubly or triply charged ions corresponding to the peptide/s selected previously from the theoretical prediction. The MS/MS peptide spectra is analyzed by assigning the fragments to the candidate sequence after calculation the series of theoretical fragmentations, according to the nomenclature of the series [38].

\subsection{Functional analysis of the identified proteins on gene expression}

Once a protein interacting with the RNA of interest is identified, several strategies can be used to study whether, or not, this factor has a role on the function of the analyzed RNA. The candidate protein can be either overexpressed or depleted, using siRNAs or shRNAs. Next, a tagged version of the protein can be expressed to reconstitute its function in depleted cells, for instance, measuring the impact of the tagged protein on the expression of reporter genes transcribed from a cotransfected dicistronic plasmid [39]. Alternatively, transfection of monocistronic constructs or viral RNAs can provide information about the level of expression of specific proteins. siRNAs targeting the mRNA encoding the protein of interest can be designed from Dharmacon (www.dharmacon.gelifesciences.com/design-center/). For siRNA silencing, HEK293 cells grown in $3.5 \mathrm{~cm}$ dishes to $70 \%$ confluent are transfected with 20-100 nM siRNA (depending upon the effectiveness of the siRNA) using lipofectamine 2000 (Life Technologies). Cell lysates are prepared 24,48 or $56 \mathrm{~h}$ later in $100 \mu \mathrm{l}$ of lysis buffer $\mathrm{C}$, and the protein concentration in the lysate measured by Bradford assay. The efficiency of interference is verified by western blot (WB). Equal amounts of total protein are resolved in SDS-gels, and then transferred to PVDF membranes (Biorad). Membranes are probed with appropriate primary antibodies; $\alpha$-tubulin (Sigma) is often used as loading control. Following incubation with the convenient secondary HRP-conjugated antibody (Thermo Scientific), proteins are revealed by ECL detection (Millipore).

\subsection{RNA-protein interaction assays}

The methodologies developed to study the type of interaction between RNA and proteins rely on the availability of appropriate tools, typically, (i) RNA synthesized in vitro which can be unlabeled, radiolabeled or fluorescent-labeled, (ii) the purified protein which is often tagged for convenient immunodetection, and (iii) a cellular extract in which the protein can be depleted or overexpressed. Using appropriate controls, these methodologies allow visualizing either the RNA or the protein bound to it, and to distinguish specific interactions from background binding.

\subsubsection{RNA synthesis}

In vitro transcription of the full-length or specific IRES domains is usually performed using T7 RNA polymerase with linearized DNA. IRES transcripts are uniformly labeled using $\alpha^{32} \mathrm{P}-\mathrm{CTP}$ $(500 \mathrm{Ci} / \mathrm{mmol})$. Then, template DNA is digested with DNase RQ1 (Promega) and the unincorporated isotope excluded using Illustra Microspin G25 columns (GE Healthcare). Labeled RNA is ethanol precipitated and resuspended in $\mathrm{TE}$ to a concentration of
$0.04 \mathrm{pmol} / \mu \mathrm{l}$. RNA integrity is examined in $6 \%$ acrylamide $7 \mathrm{M}$ urea denaturing gel electrophoresis [40].

\subsubsection{Expression and purification of proteins from bacteria or mammalian cells}

Escherichia coli BL21 transformed with bacterial expression plasmids are usually grown at $37{ }^{\circ} \mathrm{C}$ and then induced with isopropyl $\beta$-D-1-thiogalactopyranoside (IPTG) $0.5 \mathrm{mM}$ for about $2 \mathrm{~h}$. Time of induction and growth temperature needs to be optimized for each protein. In cases where the protein expression is low or even undetectable, growing the cells at lower temperatures, and/or use longer induction time may help. Bacterial lysates are prepared in binding buffer $\left(20 \mathrm{mM} \mathrm{NaH} \mathrm{PO}_{4}, 500 \mathrm{mM} \mathrm{NaCl}, 20 \mathrm{mM}\right.$ Imidazol). Cell debris is pelleted at $16,000 \times \mathrm{g}, 30 \mathrm{~min}$ at $4{ }^{\circ} \mathrm{C}$ twice. The clear lysate is then loaded on His-GraviTrap columns (GE Healthcare), washed at least twice, and the recombinant protein eluted using $500 \mathrm{mM}$ Imidazol. Proteins are dialyzed against phosphate buffer $\mathrm{pH} 6.8,1 \mathrm{mM}$ DL-dithiothreitol (DTT), and stored in small aliquots at $-20{ }^{\circ} \mathrm{C}$ in $50 \%$ glycerol until used.

For purification of proteins expressed in mammalian cells it is convenient to use tagged proteins. For instance, the vector pcDNA3/Xpress allows expression of amino terminal HIS-Xpress tagged protein [41]. Proteins can be visualized in cell lysates by $\mathrm{WB}$, and later purified by affinity procedures [32].

\subsubsection{RNA-protein photocrosslinking using purified proteins}

Uniformly radiolabeled transcripts $\left(0.04 \mathrm{pmol}, \sim 5 \times 10^{5} \mathrm{cpm}\right)$ are incubated with purified proteins (50-200 ng), depending on the factor analyzed [39]. Binding reactions are carried out in $10 \mathrm{mM}$ HEPES-KOH pH 7.4, $35 \mathrm{mM} \mathrm{KCl}, 2.75 \mathrm{mM} \mathrm{MgCl}_{2}, 10 \%$ glycerol, $0.05 \% \mathrm{NP} 40,0.5 \mathrm{mM}$ DTT, $1 \mu \mathrm{g} / \mu \mathrm{l}$ yeast tRNA, in a final volume of $16 \mu$ l. Reactions are incubated $15-20 \mathrm{~min}$ at room temperature and exposed to UV light ( $254 \mathrm{~nm}$, Stratalinker 1800, Stratagene) $3 \times 10^{4} \mu \mathrm{J}$ at a distance of $10 \mathrm{~cm}$ from the lamp. In RNA-protein competition assays, unlabeled RNA is added to the binding mixture prior to the labeled transcript $(0.025 \mathrm{pmol})$ and incubated $3 \mathrm{~min}$ at room temperature. RNA is then digested by extensive treatment with $0.3 \mu \mathrm{g} / \mu \mathrm{l}$ of RNase A during $40 \mathrm{~min}$ at $37^{\circ} \mathrm{C}$, to eliminate unbound probe and most of the unprotected RNA, except for the few nucleotides covalently linked to proteins after UV irradiation. Loading buffer is added to the samples, boiled for $2 \mathrm{~min}$, and resolved by SDS-PAGE. Subsequently, the ${ }^{32} \mathrm{P}$-labeled proteins are detected by autoradiography of the dried gels. Intensity of the crosslinked products is measured in a Phosphorimager [36].

This method is also suitable to analyze direct interactions between proteins present in S10 cell extracts and the labeled RNA when coupled to immunoprecipitation of the photocrosslinked complexes with specific antibodies, as illustrated for eIFs and ITAFs interacting with viral IRES [32,36,42-44].

\subsubsection{RNA gel-shift assays}

RNA-protein binding reactions are carried out for 20 min at $4{ }^{\circ} \mathrm{C}$ in $10 \mu \mathrm{l}$ of $40 \mathrm{mM}$ Tris- $\mathrm{HCl} \mathrm{pH} 7.5,250 \mathrm{mM} \mathrm{NaCl}, 0.1 \%(\mathrm{w} / \mathrm{v})$ 2-Mercaptoethanol ( $\beta-\mathrm{ME})$. Increasing amounts of protein are incubated with a fixed concentration of ${ }^{32}$ P-labeled RNA $(\sim 2 \mathrm{nM})$. Electrophoresis is performed in non-denaturing 8.0\% (29:1) polyacrylamide gels, run for $4 \mathrm{~h}$ in TBE buffer $(90 \mathrm{mM}$ Tris- $\mathrm{HCl}$, $64.6 \mathrm{mM}$ boric acid, $2.5 \mathrm{mM}$ EDTA pH 8.4) at $100 \mathrm{~V}$ at $4{ }^{\circ} \mathrm{C}$. Dried gels are exposed to a PhosphorImager screen. The intensity of the retarded complex is normalized relative to the free probe, run in parallel. The values obtained with increasing amounts of protein allow determining the RNA binding affinity to the protein of interest $[39,45]$. 


\subsubsection{RNA-protein pull-down}

An alternative method to analyze RNA protein interaction takes advantage of the use of HIS-tagged proteins. For this, Ni-NTA/HIS-protein complexes are assembled by incubating Ni-NTA agarose resin $(25 \mu \mathrm{l}$ ) (Qiagen), pre-washed four times with cold BBH buffer (10 mM HEPES-KOH pH 7.4, $100 \mathrm{mM} \mathrm{NaCl}, 2.5 \mathrm{mM}$ $\left.\mathrm{MgCl}_{2}, 0.01 \% \mathrm{NP}-40\right)$, with the polypeptide of interest $(0.7 \mathrm{pmol})$ in $100 \mu \mathrm{l}$ of $\mathrm{BBH}$ buffer during $4 \mathrm{~h}$ at $4{ }^{\circ} \mathrm{C}$ in a rotating wheel. Unbound proteins are removed by washing three times with cold BBH buffer. ${ }^{32}$ P-labeled RNA ( $80 \mathrm{fmol}$ ) is added to each protein-beads complex and incubated in cold BBH buffer in the presence of RNAc (300-fold excess) $2 \mathrm{~h}$ at $4{ }^{\circ} \mathrm{C}$ in a rotating wheel. Unbound RNA is removed by washing five times with cold $\mathrm{BBH}$ buffer. Bound RNAs are extracted with phenol-chloroform, ethanol precipitated, fractionated by $6 \%$ acrylamide $7 \mathrm{M}$ urea denaturing gel electrophoresis, and visualized by autoradiography [41].

\subsection{Protein complexes purification by TAP (tandem affinity purification)}

ITAFs interact with secondary partners, which could influence IRES-mediated translation. In this regard, proteomic analysis is a powerful tool to study protein-protein interactions in living cells using immuno-affinity chromatography followed by mass spectrometry. For this, the protein of interest is fused in-frame with an $\mathrm{N}$ - or C-terminal tag using the plasmids pcDNA3-NTAP and pcDNA3-CTAP [46]. The TAP cassette includes a distal tag derived from the IgG binding moiety of Staphylococcus aureus protein A (Protein A) and a proximal tag that is a calmodulin-binding peptide, both separated by a tobacco etch virus (TEV) protease cleavage site (Fig. 2A). To isolate the protein complexes present in mammalian cells associated to an ITAF we followed the strategy developed for yeast $[47,48]$, including modifications in the protocol to optimize purification of cytoplasmic proteins. Optional protocol variations (Fig. 2B), such as RNase treatment, allow the analysis of RNA-mediated interactions.

HEK293 cells (grown in $4 \times 150 \mathrm{~mm}$ plates) are transfected with the TAP-fusion plasmids and harvested $24-48 \mathrm{hpt}$, depending on the optimal expression time of the TAP-tagged proteins. Cell monolayers are washed with ice cold PBS and lysed in buffer LyB (10\% glycerol, $50 \mathrm{mM}$ Tris- $\mathrm{HCl} \mathrm{pH} 7.5,150 \mathrm{mM} \mathrm{NaCl}, 2 \mathrm{mM}$ EDTA, 0.1\% NP40, 2 mM DTT, Complete mini (Roche)). After spinning down for $10 \mathrm{~min}$ at $14,000 \times \mathrm{g}$ at $4{ }^{\circ} \mathrm{C}$, the supernatant is transferred to Econo-Pac column (Biorad) loaded with IgG-Sepharose beads (GE Healthcare) $(400 \mu \mathrm{l})$, prewashed ten times with $1 \mathrm{ml}$ of LyB, and incubated at $4{ }^{\circ} \mathrm{C}$ overnight with gentle rocking. Proteins are eluted by gravity flow, washing the beads five times with $20 \mathrm{ml}$ of LyB and five times with $5 \mathrm{ml}$ of TEV buffer (10 mM Tris- $\mathrm{HCl} \mathrm{pH} 8,150 \mathrm{mM} \mathrm{NaCl}, 0.5 \mathrm{mM}$ EDTA, 0.1\% NP40, $1 \mathrm{mM}$ DTT). Next, TEV protease treatment is carried out adding $1.5 \mathrm{ml}$ of TEV buffer and TEV protease (150 U) (Life Technologies) to the column, incubating $2 \mathrm{~h}$ at $4{ }^{\circ} \mathrm{C}$. The protein complexes are eluted by gravity flow. To eliminate the factors mediated by RNA bridges, the elution products are treated with RNase A $(75 \mu \mathrm{g} / 1.5 \mathrm{ml})$ during $30 \mathrm{~min}$ at room temperature.

Calmodulin-agarose resin (Agilent Technologies) $(400 \mu \mathrm{l}$ of bead suspension loaded into an Econo-Pac column) is equilibrated by washing ten times with $1 \mathrm{ml}$ of Calmodulin Binding Buffer (CBB) (10 mM Tris- $\mathrm{HCl} \mathrm{pH} 8,150 \mathrm{mM} \mathrm{NaCl}, 10 \mathrm{mM} \beta-\mathrm{ME}, 0.1 \% \mathrm{NP} 40$, $1 \mathrm{mM}$ MgOAc, $1 \mathrm{mM}$ Imidazole, $2 \mathrm{mM} \mathrm{CaCl}_{2}, 1 \mathrm{mM}$ PMSF). The elution products are mixed with $4 \mathrm{ml}$ of $\mathrm{CBB}$ and $4 \mu \mathrm{l}$ of $\mathrm{CaCl}_{2} 1 \mathrm{M}$, transferred to the column, and rocked at $4{ }^{\circ} \mathrm{C}$ during $1.5 \mathrm{~h}$. Elution is done by gravity flow, washing the beads five times with $20 \mathrm{ml}$ of CBB. Bound proteins are recovered with elution buffer (10 mM Tris- $\mathrm{HCl}$ pH 8, $150 \mathrm{mM} \mathrm{NaCl}, 10 \mathrm{mM} \beta-\mathrm{ME}, 0.1 \% \mathrm{NP} 40$, $1 \mathrm{mM}$ MgOAc, $1 \mathrm{mM}$ Imidazole, $2 \mathrm{mM}$ EGTA, $1 \mathrm{mM}$ PMSF) in
$5 \times 200 \mu \mathrm{l}$ fractions, with $10 \mathrm{~min}$ interval between elutions. Proteins are precipitated adding trichloroacetic acid (TCA) to a final concentration of $10 \%$, incubating the sample at $4{ }^{\circ} \mathrm{C}$ overnight. Samples are pelleted at $14,000 \times g$ for $15 \mathrm{~min}$ at $4{ }^{\circ} \mathrm{C}$, removing the supernatant. To ensure TCA elimination, the pellet is washed three times with $1 \mathrm{ml}$ of acetone and finally dissolved in loading buffer. A small aliquot is analyzed on silver stained SDS-PAGE gels to verify the purification of proteins associated to the TAP-ITAF protein (Fig. 2C).

The samples obtained by TAP-purification are optimal to be analyzed by Mass Spectrometry (MS), described in Section 2.1.4. Negative controls (TAP-purification of cell extracts expressing the empty TAP-tag vector) are conducted in parallel to discard background contaminants.

\subsection{GST-pull down assay}

The MS/MS technology often identifies a large amount of factors copurifying with the TAP-tagged protein of interest, irrespectively of whether the binding is direct or indirect. Pull down assays can be next used to analyze the interaction [45]. For this, the factors are purified as glutathione S-transferase (GST)-fusions [49], and the ITAF under study is purified as a HIS-tag fusion.

\subsubsection{GST-fusion protein purification}

E. coli BL21 transformed with the GST-fusion plasmids (pGEX) (GE Healthcare) grown at $37^{\circ} \mathrm{C}$ are induced with $0.5 \mathrm{mM}$ IPTG during the appropriate time (1-6h). The bacterial pellet is resuspended in $10 \mathrm{ml}$ of ice cold PBS, $2 \mathrm{mM}$ DTT. The cell suspension transferred to a clean centrifuge tube, adding one volume of $0.1 \mathrm{~mm}$ glass beads (Scientific Industries). Cells are then lysed by 8 cycles of vortexing $30 \mathrm{~s}$ with intervals of $1 \mathrm{~min}$ on ice. Cell debris and glass beads are pelleted at $16,000 \times \mathrm{g}, 30 \mathrm{~min}$ at $4{ }^{\circ} \mathrm{C}$. The supernatant is transferred to a clean $15 \mathrm{ml}$ tube, mixed with $150 \mu \mathrm{l}$ of glutathione Sepharose resin (GE Healthcare) equilibrated with PBS, $2 \mathrm{mM}$ DTT, and rotated on a wheel at $4{ }^{\circ} \mathrm{C}$ for $2 \mathrm{~h}$. Following centrifugation at $3000 \times \mathrm{g} 2 \mathrm{~min}$ at $4{ }^{\circ} \mathrm{C}$, the supernatant is discarded, the beads are resuspended in $1 \mathrm{ml}$ of PBS, $2 \mathrm{mM}$ DTT, and transferred to a $1.5 \mathrm{ml}$ tube. The resin is washed three times with $1 \mathrm{ml}$ of PBS, $2 \mathrm{mM}$ DTT, rotating $5 \mathrm{~min}$ at $4{ }^{\circ} \mathrm{C}$ and pelleted at $3000 \times \mathrm{g}, 2 \mathrm{~min}$ at $4{ }^{\circ} \mathrm{C}$. Finally, the recombinant GST-protein bound to the beads is resuspended in $30 \mu \mathrm{l}$ of PBS, $2 \mathrm{mM}$ DTT, $100 \mu \mathrm{l}$ of glycerol and stored at $-20^{\circ} \mathrm{C}$.

\subsubsection{Protein-protein binding assay}

Binding reactions are performed in binding buffer (BB) $(50 \mathrm{mM}$ HEPES-KOH pH 7.4, 100 mM NaCl, 2 mM DTT, $2 \mathrm{mM} \mathrm{MgCl}_{2}, 0.5 \%$ Igepal CA-630, 10\% glycerol) using $4 \mu$ g of the GST-protein bound to the glutathione resin, an appropriate amount of the purified HIS-ITAF (100-1000 ng) and five volumes of $\mathrm{BB}$, at $4{ }^{\circ} \mathrm{C}$ for $2 \mathrm{~h}$ rotating in a wheel. Then, the samples are pelleted at $3000 \times \mathrm{g}$, $2 \mathrm{~min}$ at $4{ }^{\circ} \mathrm{C}$, removing the supernatant. The beads pellet is washed three times with five volumes of BB rotating for $5 \mathrm{~min}$ at $4{ }^{\circ} \mathrm{C}$, centrifuging at $3000 \times \mathrm{g} 2 \mathrm{~min}$ at $4{ }^{\circ} \mathrm{C}$. Beads are then boiled in loading buffer for SDS-PAGE analysis and WB analysis using anti-GST to detect the GST-protein, and anti-HIS to detect the ITAF of interest [45].

\section{RNA structural analysis of viral IRESs}

\subsection{Analysis of sequence covariation and identification of conserved motifs}

Evolutionary conserved motifs determine the RNA structure organization of viral IRESs [50]. Conserved sequences essential 
A

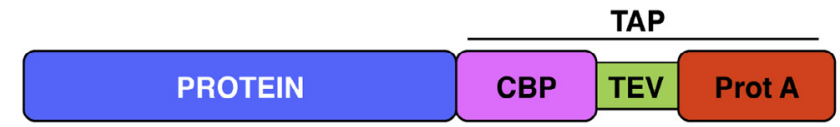

B

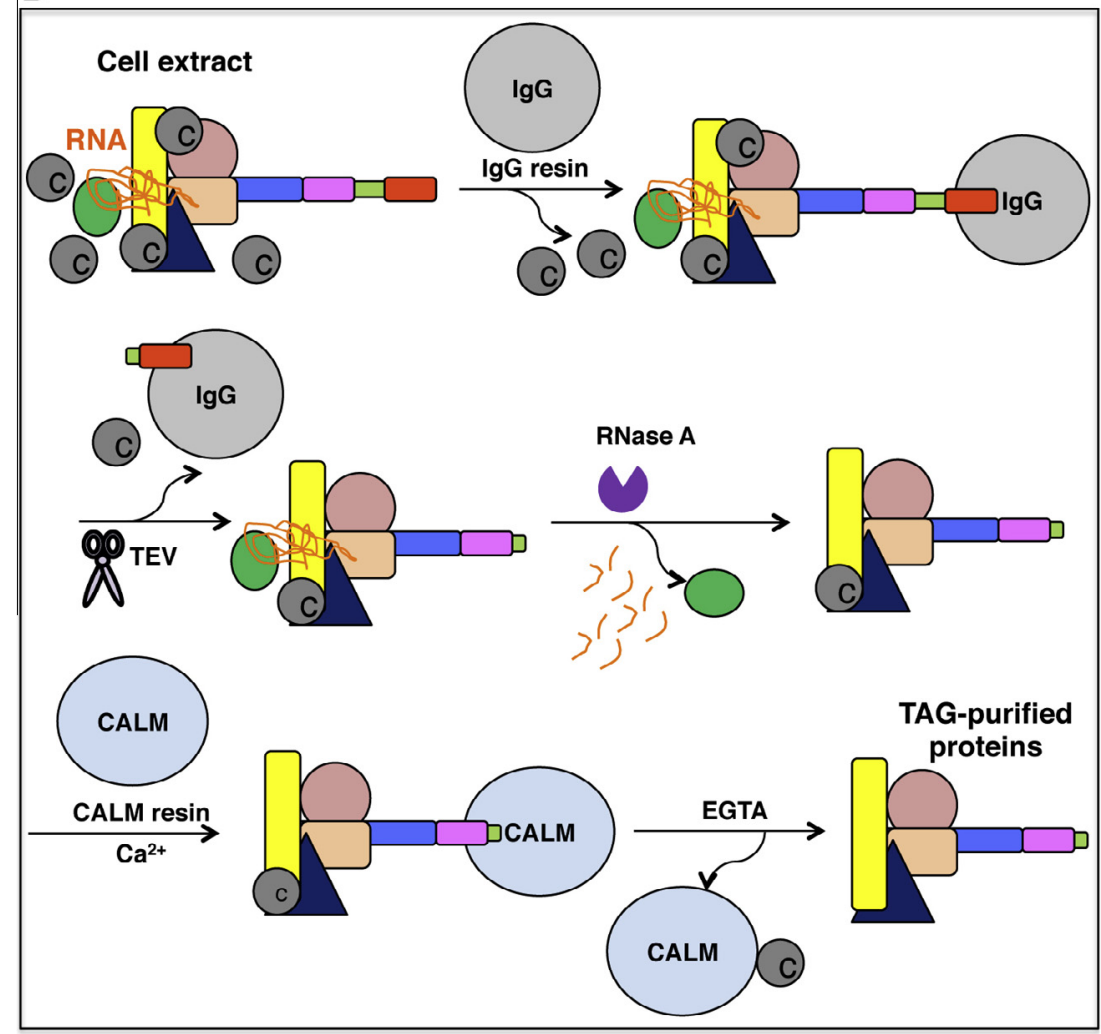

C

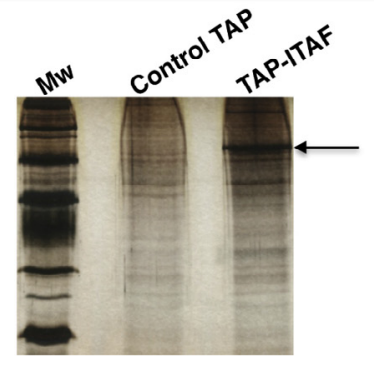

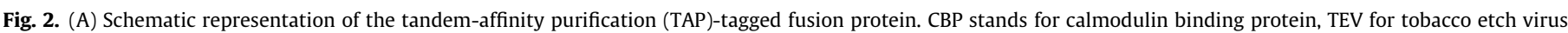

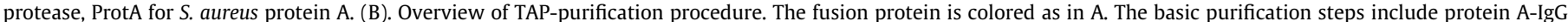

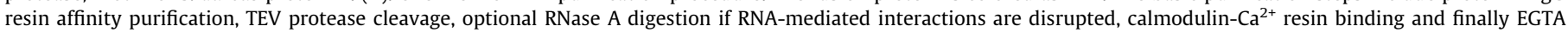

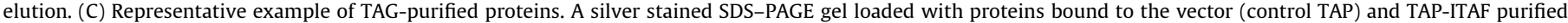
proteins. Mw depicts molecular weight markers. An arrow depicts the TAP-tagged ITAF.

for RNA function can be identified by alignment of sequences retrieved from GenBank using Blast (http://blast.ncbi.nlm.nih.gov/Blast.cgi). Duplicates and incomplete sequences must be removed and each sequence is given a unique identifier. FASTA-formatted sequences are aligned using CLUSTALW (http://www-ebi.ac.uk/Tools/clustaw2/index.html). RNA secondary structure features inferred from mutational analysis and RNA probing data are used to manually adjust the alignment.

Sequence covariation, indicative of base pairs within the RNA secondary structure, can be identified by mutual information (MI) analysis. This procedure computes the probability of finding the nucleotide $\mathrm{X}$ in position $i$ the probability of finding the nucleotide $Y$ in position $j$, and the joint probability of simultaneously finding a particular combination of nucleotides $\mathrm{X}, \mathrm{Y}$ in positions $i, j$, respectively. MI is calculated for all possible pairs of variable columns in the multiple alignment [51]. Vertical shuffling of all the columns identifies pairs with MI value significantly different from random expectation. The distribution of the MI values in randomized alignments is used to calculate the $z$-scores. Variable pairs are classified as covariant, if $z$-score $>2.96$, or independent, otherwise. Each variable pair is further classified as conservative or non-conservative, if the frequency of nt substitutions that preserved the canonical base pairing is higher or lower than $50 \%$, respectively.

Additionally, consensus sequences can be visualized by a sequence logo generated from the alignment of the IRES sequences. Nucleotide positions are represented as stacks, in which the overall height of each stack indicates the sequence conservation at that position (measured in bits), whereas the height of symbols within 
the stack reflects the relative frequency of the corresponding nucleic acid at that position (http://weblogo.berkeley.edu).

\subsection{Selective 2'-hydroxyl acylation analyzed by primer extension (SHAPE) RNA structure analysis}

Different approaches are available to determine the RNA three-dimensional structure, including X-ray, NMR, SAXS, or cryo-EM. However, these methodologies are often hard to implement due to the difficulties to obtain crystals (X-ray), the limits of the size of the RNA to be studied (NMR), or the problems to prepare stable ribonucleoprotein complexes (cryo-EM). Alternatively, local nucleotide conformation can be analyzed using other approaches in which RNA is chemically or enzymatically treated. SHAPE-probing is one of the recent advances in structural analysis of RNA molecules. In this technique, RNA is treated with a hydroxyl-selective electrophilic reagent forming 2 '-O-adducts with unconstrained nucleotides that can be later identified by primer extension reaction. This methodology offers the advantage of attacking nucleotides irrespectively of their identity, and with low influence of solvent accessibility [52]. Analysis of long RNAs in solution by SHAPE provides information on the entire element and the flanking regions, which may induce a local reorganization of the RNA element. Furthermore, it also allows one to measure the impact of RBPs and other RNA ligands on RNA structure.

This methodology includes several steps, described below.

\subsubsection{RNA treatment}

RNA ( 2 pmol) is treated with $N$-methylisatoic anhydride (NMIA) (Life Technologies) as SHAPE reagent [52]. Other SHAPE reagents [benzoyl cyanide (BzCN), 1-methyl-7-nitroisatoic anhydride (1M7), 1-methyl-6-nitroisatoic anhydride (1M6), isatoic anhydride (IA)] with different features can be selected depending on the aim of the study [53-55]. Prior to NMIA treatment, in vitro synthesized RNA is renatured by heating at $95^{\circ} \mathrm{C}$ for $2 \mathrm{~min}$, snap cooling on ice for $2 \mathrm{~min}$, and subsequently incubated in a final volume of $18 \mu \mathrm{l}$ of folding mix (100 mM HEPES-KOH pH 8.0, $0.5 \mathrm{mM} \mathrm{MgCl}_{2}, 100 \mathrm{mM}$ $\mathrm{NaCl}$ ) for $20 \mathrm{~min}$ at $37^{\circ} \mathrm{C}$. The concentration of $\mathrm{MgCl}_{2}$ can be varied between 0 to $6 \mathrm{mM}$ to study the effect of ionic strength on RNA folding [56]. Then, RNA are incubated with dimethyl sulfoxide (DMSO) (untreated RNA) or $6.5 \mathrm{mM}$ NMIA (for molecules about 1000-1300 nts long; shorter or longer RNAs may need to adjust the concentration of the reagent) for $45 \mathrm{~min}$ at $37^{\circ} \mathrm{C}$, precipitated and resuspended in $10 \mu \mathrm{l}$ of $0.5 \mathrm{X}$ TE.

\subsubsection{Primer extension}

For primer extension using fluorescently labeled primers, treated and untreated RNAs ( $2 \mathrm{pmol}$ ) are incubated with the antisense 5 -end fluorescently-labeled primer ( $2 \mathrm{pmol}$ ) (complementary to a sequence of the RNA target located 50-80 nt downstream of the sequence of interest) at $65^{\circ} \mathrm{C}$ for $5 \mathrm{~min}, 35^{\circ} \mathrm{C}$ for $5 \mathrm{~min}$ and then, chilled on ice for $2 \mathrm{~min}$. Primer extension reactions are conducted in a final volume of $16 \mu \mathrm{l}$, containing reverse transcriptase (RT) buffer $\left(50 \mathrm{mM}\right.$ Tris- $\mathrm{HCl} \mathrm{pH} 8.3,3 \mathrm{mM} \mathrm{MgCl}_{2}, 75 \mathrm{mM} \mathrm{KCl}, 8 \mathrm{mM}$ DTT) and $1 \mu \mathrm{M}$ each dNTP. The mix is heated at $52{ }^{\circ} \mathrm{C}$ for $1 \mathrm{~min}$ prior to addition of $100 \mathrm{U}$ of Superscript III RT (Life Technologies) and incubated at $52{ }^{\circ} \mathrm{C}$ for $30 \mathrm{~min}$. The enzyme is inactivated heating at $70^{\circ} \mathrm{C}$ for $15 \mathrm{~min}$. A sequencing ladder is generated using the same transcript ( $1 \mathrm{pmol}$ ), $0.1 \mathrm{mM}$ ddCTP and $0.5 \mathrm{mM}$ each dNTP. NED fluorophore (Applied Biosystems) is used for both NMIA-treated and untreated RNAs, while FAM fluorophore is used for the sequencing ladder. Primer extension products are resolved by capillary electrophoresis. A single run allows reading at least 500 nts [56].

For primer extension reactions using radiolabeled primers [51], equal amounts of NMIA-treated and untreated RNAs ( $0.5 \mathrm{pmol})$ are incubated with antisense 5 -end ${ }^{32}$ P-labeled primers ( 2 pmol) (each primer allows the analysis of around $125 \mathrm{nt}$ ) following the protocol described above. After RT reaction is completed, the RNA template is hydrolyzed in $20 \mu \mathrm{l}$ of $50 \mathrm{mM}$ Tris- $\mathrm{HCl}, \mathrm{pH} 7.5$, $7.5 \mathrm{mM}$ EDTA, $0.5 \%$ SDS adding $3.5 \mu \mathrm{l}$ of $3 \mathrm{M} \mathrm{KOH}$, incubating for $3 \mathrm{~min}$ at $95^{\circ} \mathrm{C}$ followed by $1 \mathrm{~h}$ at $37^{\circ} \mathrm{C}$. Hydrolysis is stopped adding $6 \mu \mathrm{l}$ of $3 \mathrm{M}$ acetic acid. RT-products are precipitated with $2 \mu \mathrm{g}$ of glycogen carrier and resuspended in $10 \mu \mathrm{l}$ of water supplemented with denaturing loading buffer ( $90 \%$ formamide, $1 \mathrm{mM}$ EDTA pH 8, 0.1\% xylencianol, 0.1\% bromophenol). Following denaturation during $3 \mathrm{~min}$ at $95{ }^{\circ} \mathrm{C}$, the samples are loaded in $6 \%$ acrylamide, $7 \mathrm{M}$ urea gels, in parallel to a sequence ladder prepared with the same labeled primer [56]. The extension products are visualized after autoradiography of the dried gels for about $12 \mathrm{~h}$ with intensifying screen. In all cases, formation of full-length product at the top of the gel must be verified.

\subsubsection{SHAPE data analysis}

SHAPE electropherograms obtained by capillary electrophoresis are analyzed using QuSHAPE software with default parameters [57]. The process includes four steps: (1) preprocessing of traces, (2) signal alignment (Fig. 3A), (3) sequence alignment, and (4) reactivity estimation by Gaussian peak integration (Fig. 3B). The reactivity values obtained for the untreated RNA (NMIA-) are subtracted from the NMIA-treated samples to obtain the net reactivity as a function of the nucleotide position. Reactivity data from at least three independent assays are used to calculate the mean $( \pm$ SD) SHAPE reactivity. Quantitative SHAPE reactivity for individual data sets are normalized to a scale spanning 0 to 2 (Fig. 3C), in which 0 indicates an unreactive nucleotide and the average intensity at highly reactive nts is set to 1.0 [56].

The intensities of RT-stops obtained using radiolabeled primers and conventional denaturing gel electrophoresis $[35,58]$ are quantified by densitometry using Quantity One software (Bio-Rad). The reactivity values obtained for the untreated RNA (NMIA-) are subtracted from the NMIA-treated samples. Quantitative SHAPE reactivity for individual data sets are normalized to a scale spanning 0 to 2 , in which 0 indicates unreactive nucleotides and the average intensity at highly reactive nucleotides is set to 1.0. The normalization factor for each dataset is determined by excluding the most-reactive $2 \%$ of peak intensities, followed by calculating the average for the next $8 \%$ of peak intensities. All reactivity values are normalized to this average value to generate the corresponding SHAPE reactivity profiles [52].

\subsubsection{RNA structure modeling}

Secondary RNA structure prediction accuracy can be increased incorporating SHAPE reactivity values (Fig. 3D) as constraints in RNA structure software [59]. SHAPE reactivity data is imposed as a pseudo-free energy change constraint together with nearest neighbor thermodynamic parameters using $-0.8 \mathrm{kcal} / \mathrm{mol}$ and 2.6 for the intercept $(b)$ and slope $(m)$, respectively, as recommended for large RNAs in RNA structure predictions [60]. The predicted structure corresponding to the lowest minimal free energy (MFE) energy is used to depict the RNA structure model. Secondary RNA structure is visualized with VARNA [61].

Three-dimensional RNA structure models are predicted using MC-Fold MC-Sym pipeline (www.major.iris.ca/MC-Pipeline). SHAPE reactivity can be incorporated as constraint masks in MC-Fold to obtain the secondary structure in bracket format followed by MC-Sym generator to produce the PDB RNA structure. RNA structure is visualized using Swiss-PdbViewer. The first PDB structure obtained with the MC-Sym generator using the most stable energy RNA structure according to MC-Fold is used to depict the RNA model. 
A

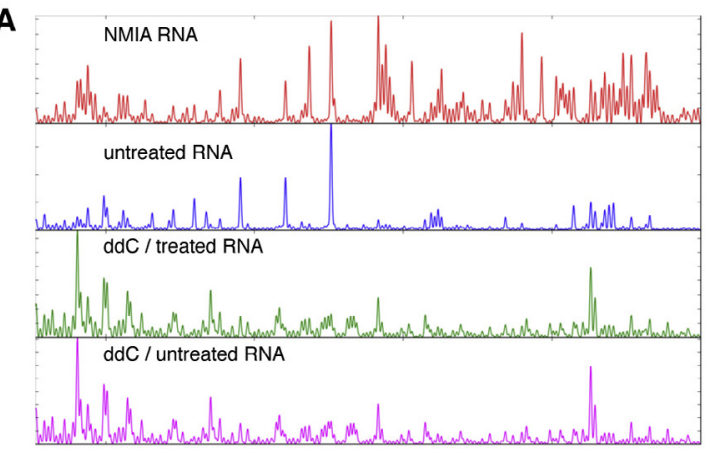

B

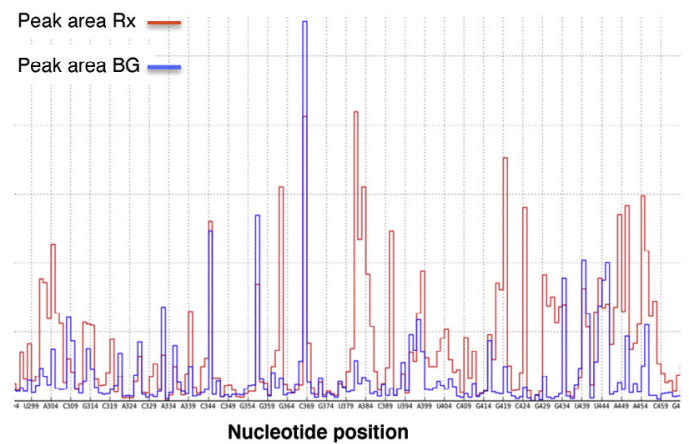

C

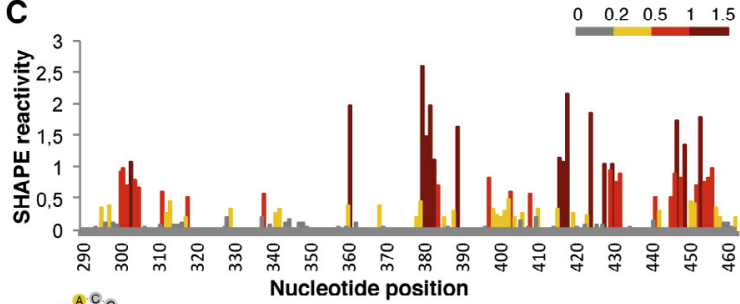

D

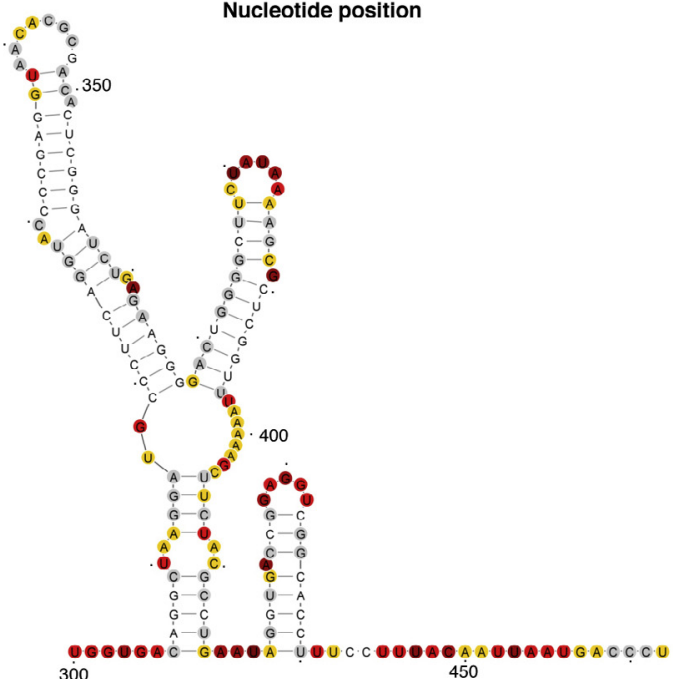

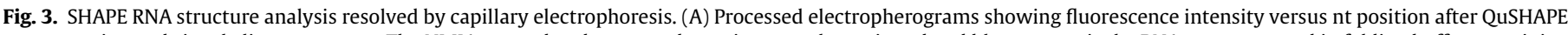

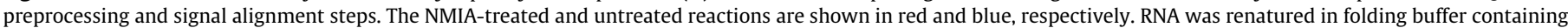

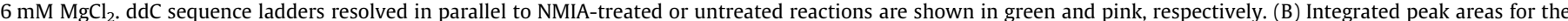

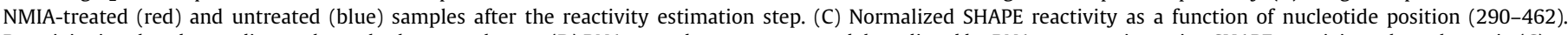

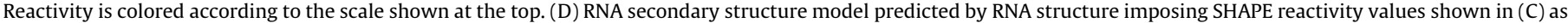
constraints.

\subsection{RNA-protein footprinting}

SHAPE chemistry is amenable to detect conformational changes in RNA structure occurring in ribonucleoprotein complexes by comparison to the pattern of reactivity of the free RNA. For this, following RNA denaturation and folding, RNA-protein (or RNA-ligand such as a small molecule or another RNA molecule) complexes are assembled for $10 \mathrm{~min}$ at room temperature in high $\mathrm{Mg}^{2+}$ folding buffer (100 mM HEPES-KOH pH 8.0, $6 \mathrm{mM} \mathrm{MgCl} 2,100 \mathrm{mM} \mathrm{NaCl}$ ) or low $\mathrm{Mg}^{2+}$ folding buffer (100 mM HEPES-KOH pH 8.0, $0.5 \mathrm{mM}$ $\mathrm{MgCl}_{2}, 100 \mathrm{mM} \mathrm{NaCl}$ ) in the presence of increasing concentrations of the protein or the RNA ligand of interest [56,58,62]. Competition between RBPs can be analyzed using a similar procedure [41]. Then, free RNA and protein-RNA complexes are treated with NMIA and analyzed by primer extension analysis, as described in Section 3.2.1.

To quantify the effect on nucleotide flexibility induced by different folding conditions or ligand binding using an unbiased approach, difference profiles are calculated by subtracting the reactivity values obtained for one condition from the reference. Increased reactivity or protected residues are reported as positive and negative values, respectively. Absolute differences in SHAPE reactivity $\geqslant 0.3$ arbitrary units and $p$-values $<0.05$ obtained by the unpaired two-tail Students $t$-test are taken to be statistically significant [55]. RNA-protein footprint can also be studied by dimethyl sulfate (DMS) treatment (see below).

\subsection{RNA structure analysis by DMS modification}

Prior to the development of SHAPE chemistry, chemical and enzymatic probing were used to study the RNA secondary structure of viral IRESs [63-65]. DMS modifies unpaired A, C and $G$ bases; however, only modified $A$ and $C$ bases halt reverse transcription reaction at the base preceding the methylated residue [66]. Occasionally, pausing of the RT reaction before a G base is observed. Monitoring of changes in the RNA folding dependent on divalent cations is ensured by comparison of the pattern of DMS attack in native $(\mathrm{N})$ versus denaturing (D) conditions. This procedure detects the appearance of residues protected from methylation in native RNA, which may be indicative of their involvement in the formation of tertiary contacts and stacking of purines in helices [67].

\subsubsection{DMS treatment of RNA in vitro}

RNA ( $1 \mathrm{pmol}$ ) is incubated in $20 \mu \mathrm{l}$ of buffer $\mathrm{N}$ ( $50 \mathrm{mM}$ sodium cacodylate $\mathrm{pH} 7.5,300 \mathrm{mM} \mathrm{KCl}, 10 \mathrm{mM} \mathrm{MgCl} 2$ ) in the presence of $1 \mu \mathrm{l}$ of DMS (Fluka) freshly diluted $1: 5$ in ethanol, $15 \mathrm{~min}$ at $20^{\circ} \mathrm{C}$. For RNA treatment under denaturing conditions, RNA dissolved in RNase-free water is first denatured during $3 \mathrm{~min}$ at $95^{\circ} \mathrm{C}$, cool down in ice, and adjusted to $20 \mu \mathrm{l}$ of buffer D (50 mM cacodylate $\mathrm{pH} 7.5,1 \mathrm{mM}$ EDTA) prior to addition of $1 \mu$ of DMS and incubation at $20^{\circ} \mathrm{C} 15 \mathrm{~min}$. The methylated RNA is ethanol-precipitated using $2 \mu \mathrm{g}$ of glycogen as carrier and resuspended in RNase free water, followed of primer extension analysis $[40,63]$.

\subsubsection{In vivo DMS footprint}

In vivo footprint takes advantage of reagents that are permeable to the cellular membrane. DMS recognizes RNA and DNA molecules in a structure-dependent manner, providing information about the accessibility of individual residues in vivo. For DMS treatment, cells (about $10^{7}$ ) are washed in cold PBS 20 hpt, scraped in 
PBS $(2 \mathrm{ml})$, pelleted and resuspended in PBS (100 $\mu \mathrm{l})$. Then, DMS $(1 \mu \mathrm{l})$ is added to the cell suspension, incubated $2 \mathrm{~min}$ at room temperature with gentle shaking [68]. Optimal DMS concentration and time of cell treatment is determined using a 10-fold DMS concentration range in parallel wells. The reaction is stopped by addition of $\beta$-ME $(10 \mu \mathrm{l})$, prior to increase the volume to $200 \mu \mathrm{l}$ with PBS and to extract total RNA using Trizol reagent (Life Technologies). As a control of untreated cells, an aliquot of transfected cells is processed in the same way except that no DMS is added.

Sites of DMS modification are identified by inhibition of RT elongation in triplicate experiments using total RNA prepared from transfected cells [68]. The optimal amount of total RNA for primer extension analysis is determined using different RNA concentrations prepared from transfected cells. Total RNA from mock-transfected cells is used as negative control. For primer extension, total RNA (about $30 \mu \mathrm{g}$ ) is denatured $3 \mathrm{~min}$ at $95^{\circ} \mathrm{C}$. Primer extension reactions are performed under the same conditions than RNA subjected to in vitro probing (see Section 3.2.2).

\section{Concluding remarks}

Here we have described distinct approaches for studying viral IRES function, IRES-protein interaction and structural organization using in vitro and in vivo methodologies. It is worth mentioning that complementary in vitro approaches, such as reconstitution of translation competent complexes using purified factors, are powerful in elucidating the mechanism used by IRESs to recruit the translation machinery. However, analyzing the factors that impact on IRES function in vivo is critical to understand the mode of action of these regulatory elements within the cell in response to different environmental factors. Transfection of dicistronic reporter constructs and viral RNA replicons in tissue culture cells has been widely used for testing IRES function. In addition, characterization of RNA-binding proteins modulating IRES activity is crucial to get a comprehensive understanding of viral IRESs, not only due to the recognition of specific RNA sequence motifs or sensing conformational changes of the IRES RNA structure, but also by reorganization of the network of proteins within the cellular compartments. Moreover, analysis of the RNA conformation in response to environmental changes, ligand binding and ribonucleoprotein complexes assembly is essential to fully understand the molecular basis of IRESs function. Currently, implementation of in vivo RNA probing methodologies with next-generation sequencing (SHAPE-seq or DMS-seq) has opened new avenues to determine the structural organization of functional RNAs within the cellular environment. Interestingly, in vivo RNA structurome studies provide information concerning a large variety of cellular processes mediated by RNA molecules, such as alternative splicing, alternative polyadenylation, energy-dependent unfolding of mRNA, and translation control. Furthermore, the IRES strategy developed by RNA viruses for protein synthesis is used by a subset of host mRNAs during cellular stress and virus infection when cap-dependent translation is inhibited. Thus, understanding the mechanism of action of the different types of viral IRESs may help to determine the mechanism by which cellular mRNAs are translated.

\section{Acknowledgements}

We are indebted to J. Ramajo, D. Piñeiro, and N. Fernandez for insightful contributions to the laboratory work. We also thank J.J. Garcia-Berlanga for the kind gift of TAP expression plasmids, and C. Gutierrez for comments on the manuscript. This work was supported by grants BFU2011-25437 and CSD2009-00080 from
MINECO (Ministerio de Economia y Competitividad), and by an Institutional grant from Fundación Ramón Areces.

\section{References}

[1] N. Sonenberg, A.G. Hinnebusch, Cell 136 (2009) 731-745.

[2] S.K. Jang, H.G. Krausslich, M.J. Nicklin, G.M. Duke, A.C. Palmenberg, E. Wimmer, J. Virol. 62 (1988) 2636-2643.

[3] J. Pelletier, N. Sonenberg, Nature 334 (1988) 320-325.

[4] E. Martinez-Salas, D. Pineiro, N. Fernandez, Comp. Funct. Genomics 2012 (2012) 391546

[5] H.H. Au, E. Jan, Wiley Interdiscip. Rev. RNA 5 (2014) 779-801.

[6] S. de Breyne, R. Soto-Rifo, M. Lopez-Lastra, T. Ohlmann, Virus Res. 171 (2013) 366-381.

[7] J.E. Wilson, T.V. Pestova, C.U. Hellen, P. Sarnow, Cell 102 (2000) 511-520.

[8] D.A. Costantino, J.S. Pfingsten, R.P. Rambo, J.S. Kieft, Nat. Struct. Mol. Biol. 15 (2008) 57-64.

[9] I.S. Fernandez, X.C. Bai, G. Murshudov, S.H. Scheres, V. Ramakrishnan, Cell 157 2014) 823-831.

[10] Y. Hashem, A. des Georges, V. Dhote, R. Langlois, H.Y. Liao, R.A. Grassucci, T.V. Pestova, C.U. Hellen, J. Frank. Nat. 503 (2013) 539-543.

[11] A.V. Pisarev, L.S. Chard, Y. Kaku, H.L. Johns, I.N. Shatsky, G.J. Belsham, J. Virol. 78 (2004) 4487-4497.

[12] T.V. Pestova, I.N. Shatsky, S.P. Fletcher, R.J. Jackson, C.U. Hellen, Genes Dev. 12 (1998) 67-83.

[13] M.E. Filbin, B.S. Vollmar, D. Shi, T. Gonen, J.S. Kieft, Nat. Struct. Mol. Biol. 20 (2013) 150-158.

[14] G. Fuchs, A.N. Petrov, C.D. Marceau, L.M. Popov, J. Chen, S.E. O’Leary, R. Wang, J.E. Carette, P. Sarnow, J.D. Puglisi, Proc. Natl. Acad. Sci. U.S.A. 112 (2015) 319325.

[15] M.I. Hertz, D.M. Landry, A.E. Willis, G. Luo, S.R. Thompson, Mol. Cell Biol. 33 (2013) 1016-1026.

[16] T.R. Sweeney, V. Dhote, Y. Yu, C.U. Hellen, J. Virol. 86 (2012) 1468-1486.

[17] E. Martinez-Salas, R. Francisco-Velilla, J. Fernandez-Chamorro, G. Lozano, R. Diaz-Toledano, Virus Res. 206 (2015) 62-73.

[18] D.E. Andreev, O. Fernandez-Miragall, J. Ramajo, S.E. Dmitriev, I.M. Terenin, E. Martinez-Salas, I.N. Shatsky, RNA 13 (2007) 1366-1374.

[19] T.R. Sweeney, I.S. Abaeva, T.V. Pestova, C.U. Hellen, EMBO J. 33 (2014) 76-92.

[20] R.E. Lloyd, Virology 479-480C (2015) 457-474.

[21] D. Walsh, I. Mohr, Nat. Rev. Microbiol. 9 (2011) 860-875.

[22] S.R. Thompson, Wiley Interdiscip. Rev. RNA 3 (2012) 697-705.

[23] M.E. Van Eden, M.P. Byrd, K.W. Sherrill, R.E. Lloyd, RNA 10 (2004) 720-730.

[24] A.M. Borman, R. Kirchweger, E. Ziegler, R.E. Rhoads, T. Skern, K.M. Kean, RNA 3 (1997) 186-196.

[25] S. Lopez de Quinto, M. Saiz, D. de la Morena, F. Sobrino, E. Martinez-Salas, Nucleic Acids Res. 30 (2002) 4398-4405.

[26] M. Kohara, T. Omata, A. Kameda, B.L. Semler, H. Itoh, E. Wimmer, A. Nomoto, J. Virol. 53 (1985) 786-792.

[27] S. Garcia-Nunez, M.I. Gismondi, G. Konig, A. Berinstein, O. Taboga, E. Rieder, E. Martinez-Salas, E. Carrillo, Virology 448 (2014) 303-313.

[28] L.B. Blyn, J.S. Towner, B.L. Semler, E. Ehrenfeld, J. Virol. 71 (1997) 6243-6246.

[29] A. Pacheco, S. Reigadas, E. Martinez-Salas, Proteomics 8 (2008) 4782-4790.

[30] A.V. Gamarnik, R. Andino, Methods Mol. Biol. 322 (2006) 367-378.

[31] J.Y. Lin, M.L. Li, S.R. Shih, Nucleic Acids Res. 37 (2009) 47-59.

[32] A. Pacheco, S. Lopez de Quinto, J. Ramajo, N. Fernandez, E. Martinez-Salas, Nucleic Acids Res. 37 (2009) 582-590.

[33] S. Weinlich, S. Huttelmaier, A. Schierhorn, S.E. Behrens, A. Ostareck-Lederer, D.H. Ostareck, RNA 15 (2009) 1528-1542.

[34] N. Locker, L.E. Easton, P.J. Lukavsky, RNA 12 (2006) 683-690.

[35] N. Fernandez, A. Garcia-Sacristan, J. Ramajo, C. Briones, E. Martinez-Salas, Virology 409 (2011) 251-261.

[36] S. Lopez de Quinto, E. Martinez-Salas, RNA 6 (2000) 1380-1392.

[37] A. Shevchenko, M. Wilm, O. Vorm, M. Mann, Anal. Chem. 68 (1996) 850-858.

[38] P. Roepstorff, J. Fohlman, Biomed. Mass Spectrom. 11 (1984) 601.

[39] J. Fernandez-Chamorro, D. Pineiro, J.M. Gordon, J. Ramajo, R. Francisco-Velilla, M.J. Macias, E. Martinez-Salas, Nucleic Acids Res. 42 (2014) 5742-5754.

[40] O. Fernandez-Miragall, R. Ramos, J. Ramajo, E. Martinez-Salas, RNA 12 (2006) 223-234.

[41] D. Pineiro, N. Fernandez, J. Ramajo, E. Martinez-Salas, Nucleic Acids Res. 41 (2013) 1017-1028.

[42] M.K. Merrill, E.Y. Dobrikova, M. Gromeier, J. Virol. 80 (2006) 3147-3156.

[43] K. Ochs, L. Saleh, G. Bassili, V.H. Sonntag, A. Zeller, M. Niepmann, J. Virol. 76 (2002) 2113-2122.

[44] S. Lopez de Quinto, E. Lafuente, E. Martinez-Salas, RNA 7 (2001) 1213-1226.

[45] K.M. Bedard, B.L. Walter, B.L. Semler, RNA 10 (2004) 1266-1276.

[46] G.I. Chen, A.C. Gingras, Methods 42 (2007) 298-305.

[47] G. Rigaut, A. Shevchenko, B. Rutz, M. Wilm, M. Mann, B. Seraphin, Nat. Biotechnol. 17 (1999) 1030-1032.

[48] R. Francisco-Velilla, M. Remacha, J.P. Ballesta, Nucleic Acids Res. 41 (2013) 8628-8636.

[49] D.B. Smith, K.S. Johnson, Gene 67 (1988) 31-40.

[50] G. Lozano, E. Martinez-Salas, Curr. Opin. Virol. 12 (2015) 113-120.

[51] N. Fernandez, O. Fernandez-Miragall, J. Ramajo, A. Garcia-Sacristan, N. Bellora, E. Eyras, C. Briones, E. Martinez-Salas, Nucleic Acids Res. 39 (2011) 8572-8585.

[52] J.L. McGinnis, C.D. Duncan, K.M. Weeks, Methods Enzymol. 468 (2009) 67-89. 
[53] S.A. Mortimer, K.M. Weeks, J. Am. Chem. Soc. 129 (2007) 4144-4145.

[54] S.A. Mortimer, K.M. Weeks, Nat. Protoc. 4 (2009) 1413-1421.

[55] K.A. Steen, G.M. Rice, K.M. Weeks, J. Am. Chem. Soc. 134 (2012) 13160-13163.

[56] G. Lozano, N. Fernandez, E. Martinez-Salas, FEBS J. 281 (2014) 3685-3700.

[57] F. Karabiber, J.L. McGinnis, O.V. Favorov, K.M. Weeks, RNA 19 (2013) 63-73.

[58] G. Lozano, A. Trapote, J. Ramajo, X. Elduque, A. Grandas, J. Robles, E. Pedroso, E. Martinez-Salas, RNA Biol. (2015).

[59] J.S. Reuter, D.H. Mathews, BMC Bioinf. 11 (2010) 129.

[60] K.E. Deigan, T.W. Li, D.H. Mathews, K.M. Weeks, Proc. Natl. Acad. Sci. U.S.A. 106 (2009) 97-102.

[61] K. Darty, A. Denise, Y. Ponty, Bioinformatics 25 (2009) 1974-1975.
[62] C. Romero-Lopez, A. Barroso-Deljesus, A. Garcia-Sacristan, C. Briones, A Berzal-Herranz, Nucleic Acids Res. 42 (2014) 567-582.

[63] O. Fernandez-Miragall, E. Martinez-Salas, RNA 9 (2003) 1333-1344.

[64] J.M. Bailey, W.E. Tapprich, J. Virol. 81 (2007) 650-668.

[65] J.S. Kieft, K. Zhou, R. Jubin, M.G. Murray, J.Y. Lau, J.A. Doudna, J. Mol. Biol. 292 (1999) 513-529.

[66] S.E. Wells, J.M. Hughes, A.H. Igel, M. Ares Jr., Methods Enzymol. 318 (2000 479-493.

[67] C. Brunel, P. Romby, Methods Enzymol. 318 (2000) 3-21.

[68] O. Fernandez-Miragall, E. Martinez-Salas, J. Gen. Virol. 88 (2007) 3053-3062. 